\title{
THE IMPORTANCE OF ADAM SMITH'S WEALTH OF NATIONS IN ENGLISH LEGAL HISTORY*
}

\author{
W. S. HOLDSWORTH†
}

$\mathrm{T}$ ALL periods in the history of English law legislation upon com-
mercial and industrial topics has occupied a large, perhaps the
largest, space in the statute book. In order to understand this legislation it is necessary to know something of the commercial and industrial conditions prevailing at the time when it was enacted, and also something of the economic theories which were accepted by the men who enacted it. In my History of English Law I have found it necessary to say something of these matters in order to render the legislation of the Middle Ages and of the sixteenth and seventeenth centuries intelligible; ${ }^{\mathrm{I}}$ and obviously in later volumes it will be as necessary to give similar information, in order to explain the very complex legislation of the eighteenth and nineteenth centuries on these matters. But the historian of the eighteenth century legislation has one advantage which he has not had in the preceding periods. This advantage is the assistance derived from Adam Smith's Wealth of Nations, which contains a critical commentary on the commercial and industrial legislation of the eighteenth and earlier centuries, and an exposition of the economic theories which were gaining in strength before he wrote, and, in consequence of his book, came to be universally or almost universally held. In this paper I propose to say something of the economic theories which were at the back of the eighteenth century legislation on commercial and industrial topics; of Adam Smith, and of the manner in which the events of his life and the qualities of his mind worked together to make his book a book of authority in the sphere of economics; and of the influence of his book on the development of the law.

At the end of the seventeenth century bodies of economic theory, and a distinctively economic point of view, were beginning to be developed. ${ }^{2}$

* A lecture delivered to the Holdsworth Club in the Faculty of Law of Birmingham University on November 3o, I934.

† Vinerian Professor of English Law in the University of Oxford; K.C., D.C.L., Hon.LL.D.

$I_{2}$ Holdsworth, History of English Law (3d ed. I923), 459-464, 466-473; 4 ibid. (I924), 326-402; 6 ibid. (1924), 3r3-360.

26 ibid. $355-356$. 
The economic theories which were being developed under the influence of this point of view were favourable to the repeal of many of the laws imposing restrictions on the freedom of industry-laws limiting prices, laws fixing the rates of wages, laws as to apprenticeship, laws against engrossing, laws which prohibited the export of bullion, laws which fixed the rate of interest. ${ }^{3}$ Such laws were condemned either because they fettered trade, or because they attempted to accomplish results which it was naturally impossible for any legislation to accomplish. ${ }^{4}$ On one or other of these grounds greater economic freedom was advocated. At the same time the economic theories which favoured economic freedom, accepted as axiomatic the mercantilist view that the legislature should regulate commerce and industry in such a way that the wealth and power of the state were increased. 5 Therefore they did not advocate anything like complete freedom of trade. Protective duties must be imposed in order to regulate foreign trade in such a way that British industries and Britain's foreign trade were encouraged. It is true that opinions differed as to the manner in which these results could best be attained. The Tory party were in favour of the policy of a comparatively free trade, because it increased the volume of trade and therefore the revenue derived from customs duties, and so lightened the burden of the taxes on land. ${ }^{6}$ The Whig party wished to encourage native industries, and therefore were in favour of prohibiting or of putting high import duties on foreign manufacturers. ${ }^{7}$ Neither party was in favour of complete freedom of trade, since both parties agreed that the state must so regulate trade that the power of the nation was increased.

The views of the Whig party prevailed during the greater part of the eighteenth century ${ }^{8}$ and their policy was successful in developing British industry and commerce. On the one hand, the legislative restrictions on freedom of industry were either repealed, or fell into disuse. ${ }^{9}$ On the other hand, colonial and foreign trade was regulated by a complex mass of statutes, which was constantly being added to or modified, in order to ensure the prosperity of the British manufacturer and trader amidst the constantly shifting commercial conditions of the day. As the eighteenth century progressed, the capitalist got more and more freedom to conduct his business as he pleased; but he still demanded and obtained protective legislation directed to maintaining his monopoly of the colonial market,

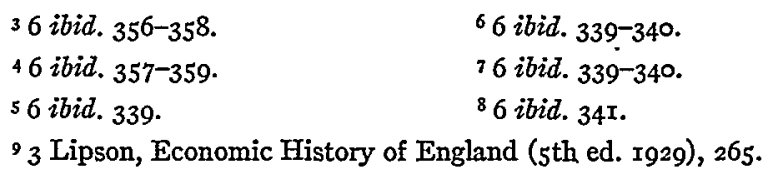


and the prevention of the competition of foreign manufacturers. Greater freedom in the conduct of industry, strict regulation of colonial and foreign trade in order to secure the prosperity of industry, were the keynotes of that mercantilist system which dominated the economic practice of the greater part of the eighteenth century. It was not till the superiority, which the new mechanical inventions had given to British industry, became decisive, that it was possible for Pitt in $I 786$ to make a commercial treaty with France which reverted to the Tory policy of a freer trade. ${ }^{10}$ It was not till after the Old Colonial Empire had been broken up by the recognition of the independence of the United States that the principle of freedom of trade began to get some recognition; ;x and it was not till I 797 that a relaxation was made in the Navigation Acts by a statute which provided that the produce of the United States could be imported in ships owned and manned by subjects of the United States. ${ }^{12}$

Long before these relaxations of the policy of high protective duties, and of the monopoly given to British ships by the Navigation Acts-relaxations which had been produced mainly by changed industrial and commercial conditions-economic opinion had been moving in the direction of the removal of many of the existing restrictions on trade both domestic and foreign. It was beginning to be thought that trade ought to be free not only from those old legislative restrictions which hampered the manufacturer, but also from these modern restrictions which the legisla-

${ }^{10} 3$ ibid. II3-116; Shelburne, in 1783 , in the speech in which he advocated free trade said:

"With more industry, with more enterprise, with more capital than any trading nation upon earth, it ought to be our constant cry, let every market be open, let us meet our rivals fairly and we ask no more." 23 Parliamentary History of England (Cobbett ed. 1814), 4 ro.

It is not surprising that nations whose commerce was less advanced refused to accede to this demand.

Ir "Lord Shelburne wrote Abbe Morellet in 1783 that the treaties of that year were inspired from beginning to end by 'the great principle of free trade,' and that 'a peace was good in the exact proportion that it recognized that principle." " Rae, Life of Adam Smith (I895), 383. In 1783 Lord Shelburne, in the debate on the articles of peace said:

"Situated as we are between the old world and the new, and between the southern and northern Europe, all that we ought to covet upon earth is free trade and fair equality. . . . . It is a principle on which we have had the wisdom to act with respect to our brethren of Ireland; and if conciliation be our view, why should we not reach out also to America." 23 Parliamentary History of England (Cobbett ed. $18 \mathrm{I} 4$ ), 409-4Io.

For Shelburne's conversion by Adam Smith to the principles of free trade, see Rae, Life of Adam Smith (1895), I53.

${ }^{12} 37$ George III ( 1797 ), c. 97, $\$$ r. In 1783 fierce opposition had been aroused by proposals to modify the principle of the Navigation Acts in favor of the Americans. 23 Parliamentary History (Cobbett ed. I8I4), 604-605, 763-764. Opposition had been aroused also by a much more modest proposal in 1785 . Ibid. $274^{-276}$. 
tures of different nations had imposed in order to protect and encourage the trade of its particular nation.

This current of opinion is connected with the idea; deduced from Locke's philosophy, that, individuals and societies ought, like the physical universe and the human understanding, to be governed by "natural laws." Those natural laws were represented as beneficent, universal, and applicable equally to all peoples. They were thus sharply contrasted with the laws of the state which were in many cases the causes of all kinds of mischief, restricted in their operation, and productive of unfair inequalities. This contrast, which was present to the mind of many political thinkers in the eighteenth century, was epigrammatically expressed by Rousseau in the opening words of his Contrat Social- "Man is born free and everywhere he is in chains." "r3 But, as De Tocqueville has pointed out, this contrast between the policy dictated by the laws of nature, and that pursued by the modern state, was emphasized by the French school of Economists or the Physiocrats more thoroughly and more strongly than by the political philosophers. That school did not stop at expounding general abstract theories: they advocated specific reforms based on those theories; ${ }^{14}$ and their advocacy of those reforms led them to construct a system which Adam Smith said was, in spite of its imperfections, "perhaps the nearest approximation to the truth that has yet been published upon the subject of political economy." ${ }_{5}$

In I793 Lord Lansdowne pointed out to the House of Lords that the "French principles," then generally denounced, had been exported by us to the French by Tucker the Dean of Gloucester and by Adam Smith. ${ }^{16}$

${ }_{3}$ "L'homme est né libre et partout il est dans les fers."

$I_{4}$ "Les économistes ont eu moins d'éclat dans l'histoire que les philosophes; moins qu'eux ils ont contribué peutêtre à l'avènement de la Révolution; je crois pourtant que c'est surtout dans leurs écrits qu'on peut le mieux étudier son vrai naturel. Les philosophes ne sont guère sortis des idées très générales et très abstraites en matière de gouvernement; les économistes, sans se séparer des théories, sont cependant descendus plus près des faits. Les uns ont dit ce qu'on pouvait imaginer, les autres ont indiqué parfois ce qu'il y avait à faire." L'Ancien Régime et la Révolution (1856), 234.

$x_{2}$ Smith, Wealth of Nations (Cannan's ed. xgo4), 176.

${ }_{16}$ "With respect to French principles, as they have been denominated, those principles had been exported from us to France, and could not be said to have originated among the people of the latter country. The new principles of government, founded on the abolition of the old feudal systems, were originally propagated among us by the dean of Gloucester, Mr. Tucker, and had since been more generally inculcated by Dr. Adam Smith, in his work on the Wealth of Nations, which had been recommended as a book necessary for the information of youth by Mr. Dugald Stewart, in his Elements of the Philosophy of the Human Mind." 30 Parliamentary History of England (Cobbett ed. I8I7), 329-330, cited in Rae, Life of Adam Smith (1895), 291. 
Lord Loughborough replied that in the works of Tucker and Adam Smith "no doctrines inimical to the principles of civil government, the morals or religion of mankind were contained; and therefore to trace the errors of the French to these causes was manifestly fallacious." ${ }^{17}$ But there is no doubt that Lord Lansdowne was right in his contention that the "French principles," and the theories of free trade held by the Physiocrats and by Adam Smith, had a common ancestor in their appeal to the elusive law of nature; and there is no doubt also that Bentham's theories were not remotely connected with that same law, disguised so effectually as the principle of utility, that Bentham himself failed to penetrate the disguise. ${ }^{8}$ There was thus some reason in the views of those who held that the new economic doctrines were not totally unconnected with the French revolutionary ideas. ${ }^{19}$ In fact, the movement in the direction of rationalizing the laws and institutions of Europe, by an appeal to $a$ priori principles founded on reason or utility or natural law, was giving rise to bodies of political or economic doctrine, and to projects of reform, which varied with the intellectual environment of the writer and the conditions of the society in which he found himself. But, though the doctrines and the projects were diverse, they all belonged intellectually to the same school of thought.

In many respects the principles taught by Adam Smith are identical with those taught by the Physiocrats. It is true that one of their central tenets was rejected by Adam Smith, and never came to be part of accepted economic doctrine. This was the theory that it was only those industries which added to the mass of raw material, such as agriculture or mining, which were really productive, because they alone gave rise to a "produit net," that is something over and above the cost of labour and the interest on capital..$^{20}$ But this divergence of view is the exception

17 Parliamentary History, 30 Parliamentary History of England (Cobbett ed. 18I 7), 334 .

${ }^{8}$ Dicey, Law and Opinion in England (Ist ed. 1905), I43-I44.

99 In r793-I794 Dugald Stewart read his memoir on Adam Smith to the Royal Society of Edinburgh, and he was compelled to abandon his idea of giving a long account of Adam Smith's opinions, because "it was not unusual, even among men of some talents and information, to confound studiously the speculative doctrines of political economy with those discussions concerning the first principles of government, which happened at that time unfortunately to agitate the public mind. The doctrine of Free Trade was itself represented as of a revolutionary tendency." Stewart's Works, 87, cited in Rae, Life of Adam Smith (1895), 292.

30 For this theory see Palgrave, Dictionary of Political Economy (I894), Physiocrats; Bagehot, Biographical Studies (xgo2), 266-269; Cannan, Introduction to Wealth of Nations (Cannan's ed. I904), xxx-xxxiii. Adam Smith says:

"That system which represents the produce of land as the sole source of the revenue and wealth of every country has, so far as I know, never been adopted by any nation, and it at 
rather than the rule. In their broad essential outlines their principles are similar; and it is these principles which were the foundation and starting point of the reasoning of the English school of classical economists. Thus the idea that the wealth of a nation consists of the annual produce of the nation annually distributed was directly derived from this school ${ }^{22}$ and the formula "laissez faire, laissez passer" was invented by one of its members. That formula expresses the view, at which Adam Smith had arrived independently, that the laws of nature, if left to themselves, would produce ideally just results. It followed that, if the state confined itself to the protection of person and property, if it ceased to impose restrictions on industry and commerce and left individuals free to conduct their business as they pleased, the natural desire of each individual to benefit himself would increase the wealth of the nation more quickly and certainly than any of the restrictive laws which aimed at producing this result. ${ }^{22}$ But if the policy of laissez faire produced all the beneficent results claimed for it, and if the object at which the state ought to aim was the increase of the nation's wealth, the state should leave individuals free to produce and distribute as much as they could, and not restrict their activities by laws passed to secure the supposed interests of the state, still less by laws which gave unfair advantages to particular individuals or to corporations. ${ }^{23}$ "It is the highest impertinence and presumption in kings and ministers," said Adam Smith, "to pretend to watch over the economy of private people, and to restrain their expence, either by sumptuary laws, or by prohibiting the importation of foreign luxuries. They are themselves always, and without any exception, the greatest spendthrifts in the society." ${ }^{24}$ It is not surprising that Adam Smith, though he rejected the

present exists only in the speculations of a few men of great learning and ingenuity in France." Wealth of Nations (Cannan's ed. I904), I6I.

2x Cannan, Introduction to Wealth of Nations (Igo4), xxxl, xxxlii.

22 Infra, p. 54x.

${ }_{23}$ "The requirements of the State had been the first consideration of seventeenth century writers, and they had worked back to the funds in the possession of the people from which these requirements could be supplied. Adam Smith approached the subject from the other end. The first object of political economy as he understood it, was 'to provide a plentiful revenue or subsistence for the people,' the second was 'to supply the State or commonwealth with a revenue sufficient for the public services.' He simply discussed the subject of wealth; its bearing on the condition of the State appeared an afterthought. . . . . When the new conception was once clearly grasped it became obvious that interference with any individual, in the way he conducts his business, can scarcely ever be justified on strictly economic grounds, and that costly attempts to foster exotic trades or to stimulate native industries are on the face of it absurd." 2 Cunningham, Growth of English Industry and Commerce (5th ed. I9I2), 593-594, 595 .

${ }^{24}$ I Smith, Wealth of Nations (Cannan's ed. I904), 328. 
central tenet of the Physiocratic school, should say that they had more nearly approximated to the truth than any preceding economic writers. ${ }^{25}$

In the third quarter of the eighteenth century the doctrines of this French school of economists were the largest body of systematic economic theory. But this body of economic theory did not stand alone. During the eighteenth century there had been much scattered economic speculation in England; and in Scotland this speculation had begun to assume a more systematic and a more scientific form. From the seventeenth century onwards Scotsmen have been great systematizers-remarkable for their "power of reducing human actions to formulae or principles." 26 This power, due perhaps in the first instance to the dominance of the Calvinistic theology, remained after the leaders of Scottish thought had emancipated themselves from the leading strings of that theology; and it helped to produce that taste for abstract speculation upon metaphysics, morals, politics, and economics, which is apparent both in the teaching of the Scottish universities and in the writings of eminent Scotsmen of this period. Hutcheson, the professor of moral philosophy at Glasgow when Adam Smith was a student, lectured not only on ethics but also on Jurisprudence and Civil Polity; and in his lectures on the two latter subjects "a considerable quantity of economic doctrine is scattered." ${ }^{27}$ We shall see that the tradition thus attached to this chair influenced Adam Smith when he came to hold it. ${ }^{28}$ Hume's Essays on various economic subjects, which were first published in $\mathrm{I}_{752}$, had criticized prevalent fallacies as to the function of money, and the doctrines held by writers of the mercantilist school as to the balance of trade. ${ }^{29}$ In ${ }_{17} 67$ Sir James Stewart had published what Dr. Cannan calls a great book on political economy. ${ }^{30}$ Thus Adam Smith, as a Scotsman and as a student of Glasgow University, was educated in an atmosphere which was favourable to a study of economic theory. That he succeeded in writing a book, of which it was truly said that it "would persuade the present generation and govern the next," ${ }_{3 \mathrm{I}}$ was due partly to his own abilities, and partly to the manner in which he

${ }_{25}$ Supra note 5 . ${ }_{26}^{26}$ Bagehot, Literary Studies (4th ed. $189 \mathrm{I}$ ), 247.

${ }_{27}$ Cannan, Introduction to Wealth of Nations, xxxvi; for details see ibid. xxxvii-xli.

${ }^{8}$ Infra, pp. 540-54r. $\quad 29$ Hume, Essays (r768), 285-373.

${ }^{30}$ Cannan, Introduction to Wealth of Nations, xviii. Its title was, An Inquiry into the Principles of Political Economy: being an Essay on the Science of Domestic Policy in Free Nations.

3I "It was Pulteney (one of Adam Smith's pupils) who, in his speech on the suspension of cash payments by the Bank of England in I797 . . . quoted from some unknown source the memorable saying, which is generally repeated as if it were his own, that Smith 'would persuade the present generation and govern the next." "Rae, Life of Adam Smith (1895), ro3. 
made the most of the opportunities which the events of his life gave to him.

Adam Smith was born at Kirkcaldy June $5,1723 .{ }^{32}$ He was a student at Glasgow University between $\mathrm{I} 737$ and 1740 . Between $\mathrm{7} 740$ and $\mathrm{x} 746$ he was a Snell exhibitioner of Balliol College Oxford. Though, like Gibbon, he justly condemned the state of Oxford University, ${ }^{33}$ he carried away a knowledge of Greek which was superior to that of his Scotch contemporaries, and, what was more important, a knowledge and an understanding of the English point of view, without which he could never have written a book which was immediately recognised as a classic. ${ }^{34}$ After his return to Scotland he lectured at Edinburgh between the years $x 748$ and r750. One of these courses of lectures was on economics, and in it he advocated those ideas of commercial liberty which he had learned from Hutcheson, and of which he was afterwards to be so great an exponent. ${ }^{35}$ In I75I he became professor of Logic at Glasgow; but in I752 he exchanged this chair for that of Moral Philosophy. He held this chair till I764; it was during these years, and in those parts of his lectures on Jurisprudence, which he called "Police, Revenue, and Arms," that he laid the foundations of his book on the Wealth of Nations. ${ }^{36}$

It was under the head "Police" that he dealt with economic topics. "The name "police," he said, "is French and is originally derived from the Greek $\pi 0 \lambda \iota \tau \epsilon^{\prime} a$, which properly signified the policy of civil government, but now it only means the regulation of the inferior parts of

${ }^{32}$ The best authority for Adam Smith is Rae's Life of Adam Smith; $c f$. also Dict. Nat. Biog. and Encyclopaedia Britannica. Bagehot's essay on Adam Smith as a Person, Biographical Studies ( $x 902), 247-28 \mathrm{r}$, though suggestive, is inaccurate in many respects.

${ }_{33}$ "In the university of Oxford, the greater part of the public professors have, for these many years, given up altogether even the pretence of teaching." 2 Wealth of Nations (Cannan's ed. r904), 25 r.

34 See Bagehot, supra note 26, 252-253.

35 Rae, Iife of Adam Smith (1895), 36; Dugald Stewart cites a paper written by Adam Smith in 1755 , in which Smith claimed that, as early as 1749 , he had maintained in his lectures that "projectors disturb nature in the course of her operations on human affairs, and it requires no more than to leave her alone and give her fair play in the pursuit of her ends, that she may establish her own designs. . . . . Little else is required to carry a state to the highest degree of affluence from the lowest barbarism but peace, easy taxes, and a tolerable administration of justice. All governments which thwart this natural course . . . . are unnatural, and to support themselves are obliged to be oppressive and tyrannical." Ibid. 62-63.

${ }^{36}$ Ibid. 6x; I Smith, Wealth of Nations (Cannan's ed. Ig04), Introduction, xxiii-xix; a copy of the notes of these lectures taken by a student in $I 763$ has been edited by Cannan; as Professor Scott says in his lecture on Adam Smith, Proceedings of the British Academy $x, 45$. they show that the fundamental principles embodied in the Wealth of Nations "were being taught in the class room at Glasgow." - 
government, viz. cleanliness, security and cheapness." 37 It was under the head of 'cheapness' that Adam Smith lectured on "the opulence of a state," and the notes which we have of his lectures show that he had begun to maintain those principles which were to make his Wealth of Nations famous. ${ }^{38}$ Some of his ideas he got from Hutcheson's System of Moral Philosophy, which no doubt contained the gist of the lectures which Smith had listened to as a student. ${ }^{39}$ Hutcheson had dealt with such topics as the division of labour, value, money, prices, interest, profits, taxation; and he showed that many of these matters were regulated by natural causes, which cannot be controlled by the Legislature ${ }^{40}$-a point of view which fitted in very well with his insistence on the importance of preserving civil and religious liberty..$^{4 x}$ His teaching made a great impression on Adam Smith. ${ }^{42}$ It suggested to him the topics of his lectures on economic subjects, ${ }^{43}$ it gave him the idea of investigating the natural causes which determined these phenomena, and it gave him that bias in favour of liberty which is strongly marked in all his writings. But to these ideas Adam Smith added others of much greater importance. In the first place, his "belief in the economic beneficence of self interest," which as Dr. Cannan has said, "permeates the Wealth of Nations and has afforded a starting ground for economic speculation ever since," 44 was probably derived, at least in part, from Mandeville. ${ }^{45}$ Smith combined the bias in favour of liberty, which he had learned from Hutcheson, with this belief in the economic beneficence of self interest, when he said that "in general, if any branch of trade, or any division of labour, be advantageous to the public, the freer and more general the competition, it will always be the more so $;^{46}$ and that, "the natural effort of every individual to better his own condition, when suffered to exert itself with freedom and security, is so powerful a principle, that it is alone, and without any assistance, not only capable of carrying on the society to wealth and prosperity, but of

${ }^{37}$ I Smith, Wealth of Nations (Cannan's ed. I904), Introduction, xix.

${ }^{8}$ Ibid. xx-xxvii.

10 Ibid. xxxvi-xli; cf. Rae, Life of Adam Smith (r895), 14-I5.

39 Ibid. xxxvi. 45 Ibid. I3.

${ }^{2}$ In ${ }^{7} 787$ Smith, in writing to the Principal of Glasgow University to accept the office of Rector to which he had just been elected, spoke of "the abilities and virtues of the never-to-beforgotten Dr. Hutcheson." Ibid. 4xx.

43 I Smith, Wealth of Nations (Cannan's ed. rg04), Introduction, xli.

44 Ibid. xli-xlii.

${ }^{45}$ Ibid. xliii-xlvi; Dr. Cannan points out that Smith, twenty years after attending Hutcheson's lectures, criticized him "expressly on the ground that he thought too little of self-love." Ibid. xlii.

$4^{6}$ I Smith, Wealth of Nations (Cannan's ed. r904), $3^{\text {I2 }}$. 
surmounting a hundred impertinent obstructions with which the folly of human laws too often incumbers its operations." 47 In the second place, his belief in the principle of free trade, and his criticism of the mercantile system, was probably derived from Hume's Essays. "It seems very likely," says Dr. Cannan, ${ }^{88}$ "that the reference in the lectures to Hume's 'essays showing the absurdity of these and other such doctrines' is to be regarded as an acknowledgement of obligation, and therefore it was Hume, by his Political Discourses on Money and the Balance of Trade

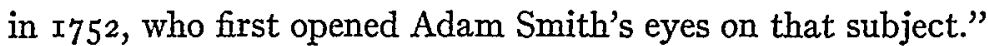

Adam Smith, like other political philosophers or economists, owed intellectual debts to his predecessors and contemporaries; and it is possible to trace the sources of many of his economic theories. But though he was a student and a critic of other men's theories, though he himself was a great and original exponent of economic theory, he was far from being a mere theorist. It is clear that, though occasionally afflicted with fits of absence of mind which have given occasion to many anecdotes, ${ }^{49}$ he was not merely "an awkward Scotch professor, apparently choked with books and absorbed in abstractions." ${ }^{\circ 0} \mathrm{He}$ took a more active part in the life of his university than any other professor, and acted as college Quaestor or Treasurer from $175^{8}$ to $1764^{5 \mathrm{I}} \mathrm{He}$ had many friends amongst the Glasgow merchants; and one to these was Andrew Cochrane who founded a political economy club in I743, of which Adam Smith was a member..$^{52}$ It is clear that the discussion of such questions as export and import duties, and the advantages and disadvantages of paper money, by practical merchants at such a club, gave him a knowledge of commercial conditions, without which he could not have based his economic theories on the solid foundation of the commercial and industrial facts of his day. As we shall see, it was because Adam Smith, at this and at other periods of his life,53 never lost sight of the actual concrete facts on which his theories were

${ }^{47} 2$ Ibid. 43.

${ }_{48}^{8}$ I Smith, Wealth of Nations (Cannan's ed. I904), Introduction, xlvi-xlvii.

49 For some of these anecdotes see Rae, Life of Adam Smith (I895), 245-246, 259-260, 329, 330-332; Bagehot, Biographical Studies (I902), 247-248.

so Ibid. 247; this statement of Bagehot is disproved by Rae; Mr. Rae says, supra 56 : "a - common misconception regarding Smith is that he was as helpless as a child in matters of business. . . . . This idea of his helplessness in the petty transactions of life arose from observing his occasional fits of absence and his habitual simplicity of character, but his simplicity, nobody denies, was accompanied by exceptional acuteness and practical sagacity, and his fits of absence seem to have been neither so frequent nor so prolonged as they are commonly represented."

${ }^{5}$ Rae, stipra note 35, 66-69.

$5^{2}$ Ibid. 91, 92-93.

${ }^{53}$ Ibid. 2x, 22, 23-24. 
based, that those theories exercised so great an influence on his own and on succeeding ages. At the same time he was a member of other societies in Glasgow and Edinburgh in which literary and artistic and scientific problems were discussed; ${ }^{54}$ and all this discussion must have helped him both to collect the facts upon which his theories were founded, and to correct, to qualify, and to give precision to his theories.

Adam Smith's lectures at Glasgow made him famous, and it was said that, during the thirteen years that he held his chair, he had converted the leading men at Glasgow to his free trade views. ${ }^{55}$ But Smith was not a professor of political economy. He was a professor of moral philosophy, and his economic teaching was only a part of his subject. The first book which he published was a book on a subject which, to modern ideas, was more closely connected with the subject of his chair than jurisprudence or economics. It was entitled a Theory of Moral Sentiments, and was published in r759. It was a very successful book, and at once gave Adam Smith a high place amongst his contemporaries. ${ }^{56}$ But its historical importance is due to the fact that it changed the course of Adam Smith's life, and gave him opportunities of a unique kind for the prosecution of his economic studies. Charles Townshend, the stepfather of the young Duke of Buccleugh, was so attracted by Adam Smith's book that he offered Adam Smith the post of tutor to the Duke on his travels abroad. Smith was to have $£_{300}$ a year and traveling expenses while abroad, and a pension of $£_{3} 00$ a year for life afterwards. "He was thus to have twice his Glasgow income, and to have it assured till death." 57 Smith accepted this offer, gave up his professorship, and travelled with his pupil in France between the years 1764 and 1766 . It was this journey abroad which gave him the opportunity to discuss economic problems with Quesnay the leader of the Physiocrats, with Turgot, and with many of the other leaders of the French school of economic thought; and there is no doubt that this inspired important parts of the Wealth of Nations, and that it gave him an insight into the strength and weaknesses of this school, and into the working of French institutions, which he could never have learned from books..$^{8}$ It was the pension which was settled upon him

54 Ibid. 94-96, IO7-Ir8, I34-ז40.

ss Ibid. 60-6I.

${ }^{56}$ Ibid. $\mathrm{I}_{4} \mathrm{I}$; see Hume's letter of congratulations, ibid. I4I-I44.

57 Ibid. 165 .

${ }_{58}$ "When we find that there is no trace of these theories (of the Physiocrats) in the Lectures and a great deal in the Wealth of Nations, and that in the meantime Adam Smith had been to France and mixed with all the prominent members of the 'sect,' including their master, Quesnay, it is difficult to understand why we should be asked, without any evidence, to refrain 
for life which enabled him, after this return, to devote all his energies to the writing of his book.

From 1767 to $x 773$ he lived with his mother at Kirkcaldy, and devoted himself so industriously to the writing of his book that his labours told on his health. In I773 he thought that he had practically finished it, and went to London with the manuscript. But when he got to London he found that it needed so many additions and alterations that it was not published till 1776 . There is no doubt that, just as discussions with the Glasgow merchants, at various literary societies in Glasgow, and with the French economists in Paris, had presented new material and new points of view which he had assimilated and incorporated into his book, so discussions with many of the leading literary men in London, at Johnson's Literary Club and elsewhere, showed the need for amplification and modification. Thus, to take one instance, Smith saw much of Benjamin Franklin, whom he had met in Edinburgh in I759; and there is no doubt that it was from Franklin that he got much of that information about the American colonies of which he makes so much use in the Wealth of Nations. 59

At length the book appeared on March 9, 1776 . Its merits were at once recognised by such literary judges as Hume and Gibbon; ${ }^{60}$ Lord North's budgets of 1777 and $I 778$ adopted ideas taken from it; ${ }^{.6}$ in 1779 Smith was consulted by Dundas and the Earl of Carlisle on the subject of free trade with Ireland, ${ }^{62}$ and in $x 783$ he was consulted by Eden on the subject of freedom of trade between Canada and the United States. ${ }^{63} \mathrm{~A}$

from believing that he came under physiocratic influence after and not before or during the Glasgow period." I Smith, Wealth of Nations (Cannan's ed. 1904), Introduction, xxx-xxxi.

On the other hand the influence of the French school must not be exaggerated; we have seen that Adam Smith had arrived independently at the same conclusions. I Smith, Wealth of Nations, I6-I8; as Professor Scott says:

"There is first the main question of similarity in thought; and, when this is considered in relation to the chief currents of opinion in the eighteenth century, it will be found that it was not so much a question of the indebtedness of Smith to the Physiocrats as of both types of thought having a common source in the Nature-cult of the time." Proceedings of the British Academy $x, 450$.

59 Rae, supra note $35,264-266$ :

"Dr. Franklin once told Dr. Logan that the celebrated Adam Smith, when writing his Wealth of Nations, was in the habit of bringing chapter after chapter as he composed it to himself, Dr. Price, and others of the literati; then patiently hear their observations and profit by their discussions and criticisms-even sometimes submitting to write whole chapters anew, and even to reverse some of his propositions." J. F. Watson, Annals of Philadelphia, 533. (r8gr.)
${ }^{60}$ Rae, supra note $35,286-287$.
62 Ibid. $349-355$.
6z Ibid. 294.
${ }_{3}$ Ibid. $383-386$. 
second edition appeared in 1778 with some additions and corrections. To the third edition, published in 1784 , considerable additions were made. ${ }^{64}$ In 7778 Lord North had appointed Adam Smith commissioner of customs in Scotland-an appointment which there is some reason to think was due, not so much to the influence of the Duke of Buccleugh and Dundas, as to Lord North's recognition of the value of his book. ${ }^{65}$ Now as ever, Smith was always ready to use new information to improve his book. Some of the additions which he made to the third edition are due to the first hand information which he had got as commissioner of customs, ${ }^{66}$ e.g., the account of the working of the bounty system in the Scotch fisheries; ${ }^{67}$ some both to this information and to the further reading and reflection which it suggested, e.g., the chapter entitled 'Conclusion of the Mercantile System'; and some to current political discussions, e.g., the account of the chartered companies and especially the detailed account of the East India Company ${ }^{68}$ The fourth and fifth editions published in I 786 and 1789 contain no material alterations. ${ }^{69}$ Smith died July I 7 , I 790, so that the fifth edition was the last published in his life-time.7०

The importance of Adam Smith's book to the historian of English law is this: It is the best commentary, not only upon the commercial and industrial legislation of the eighteenth century, but also upon many aspects of its public law. It gives us not only a lucid account of the most important of the statutes bearing upon industrial and commercial law, and upon many aspects of public law, but also the criticisms of one of the ablest men of the century upon these topics. And they are the criticisms of a man who had derived his knowledge of these statutes and of the law which they added to or amended, not only from books, but also from converse with men whom these statutes or this law affected, and with men who had helped to enact them. There is a very large concrete element in Adam Smith's book, which is due to the manner in which, from his days as a Glasgow professor to the end of his life, he got his materials at first

64 I Smith, Wealth of Nations (Cannan's ed. I904), Introduction, xiii-xvii.

${ }^{65}$ Rae, supra note $35,320-32 x$; on receiving this appointment he offered to give up his pension from the Duke of Buccleugh, but he was informed that "the pension was meant to be permanent and unconditional, and that if he were consulting his own honour in offering to give it up, he was not thinking of the honour of Lord Buccleugh." Ibid. 32r. Bagehot, supra note 49, 262-275, has given an incorrect account of this episode.

66 Rae, supra note 35, 332-333.

${ }_{7}$ Ibid. 363 . ${ }^{68}$ Ibid.

69 x Smith, Wealth of Nations (Cannan's ed. x904), Introduction, xvii-xviii.

${ }^{\circ}$ This is the edition which is taken by Dr. Cannan as the text of his definitive edition of the Wealth of Nations. 
hand from his own experience or from men who had first hand experience. It is this concrete element which caused his contemporaries at once to accept his book as a book of authority, and makes it so essential an authority for the legal history of this period. And the importance of the book to the legal historian is by no means confined to the light which it throws upon the law of the eighteenth century. Because it inspired the policy of the legislature, and therefore the contents of the statute book, for very many years afterwards, it is the best guide to an understanding of this legislation. ${ }^{7 x}$ But this aspect of the book is due not only to what I have called its concrete character, but to the nature of the theories by which it was inspired, and in the light of which the mass of concrete facts and statutes and institutions which it details or describes, is interpreted.

We have seen that all through his book Smith is an advocate, first for the liberty of the individual, and, secondly, for the thesis that, inasmuch as "man's self love is God's providence," this liberty, if left to itself, will produce the best economic results. ${ }^{72}$ It followed that the wealth of a nation could best be attained not, as the mercantilists thought, by restrictive legislation directed to secure the prosperity of a particular state at the expense of rival states, ${ }^{73}$ but by leaving each individual as free as possible to conduct his own trade in his own way. Laissez faire, and the working of natural economic laws would do the rest. It is from this point of view that Smith criticizes all the commercial and industrial laws of his day; and it is from this point of view that he lays down his celebrated canons of taxation as a basis for his criticism of existing systems of taxation. ${ }^{74}$ But merely abstract theories, economic or otherwise, produce little effect unless they are brought into relation with concrete facts. It is because Adam Smith's theories are based upon and correlated with the facts of his day that they exercised so great an influence upon his contemporaries. Because the theories set forth in the Wealth of Nations were the theories of a man who knew the facts and the law, of a man who under-

$7 x$ In I792 Pitt said of Adam Smith's book that, by reason of the author's "extensive knowledge of detail and depth of philosophical research," it furnished "the best solution to every question connected with the history of commerce, or with the systems of political economy." 29 Parliamentary History of England (Cobbett's ed. 2817 ), 834.

${ }^{2}$ Supra p. 54I.

73 "By such maxims as these nations have been taught that their interest consisted in beggaring their neighbors. Each nation has been made to look with an invidious eye upon the prosperity of all the nations with which it trades, and to consider their gain as its own loss. Commerce, which ought naturally to be, among nations, as among individuals, a bond of union and friendship, has become the most fertile source of discord and animosity." I Smith, Wealth of Nations (Cannan's ed. I904), 457 .

742 ibid. 310-312. 
stood their practical working and could criticise them intelligently, they convinced English statesmen, just as his lectures in Glasgow had convinced the Glasgow merchants. ${ }^{75}$ Like Bentham in the sphere of law, he convinced his contemporaries of the soundness of his theories by the manner in which he applied them in detail to the facts of the system which he was criticizing, and by the practical suggestions which he made as the result of this application of his theories to the facts. ${ }^{76}$

It is this characteristic of Smith's work which differentiates it from the work of the Physiocrats. Their theories were based upon a series of logical deductions from their ideas as to Natural Right, and Natural Order. "This logical method," says Professor Scott,77 "enabled a system to be constructed, and it was at once the strength and weakness of the schoolits strength in giving economic phenomena not only a scientific treatment, but a scientific form, its weakness in the absolute dependence of the latter upon the Nature-cult as they defined it." From the fallacies which arose from the exclusively logical method of approaching the subject, Adam Smith's knowledge of the political and business worlds of his day saved him, and enabled him to keep his theories in touch with the concrete facts of those worlds. It was for this reason that his influence on his own contemporaries and on the succeeding generation was so great..$^{78}$

It is this same characteristic of his work which saved him from some of the errors into which his successors and followers fell. As Cunningham has pointed out, "79 "he dealt with concrete instances and the actual life of a nation. His disciples followed him in separating out the economic side of human life, but they treated it as if it were an independent entity, and not as conditioned by the political circumstances of the community, and by the personal welfare of the citizens." Thus he approved of the policy of the Navigation Acts; $;^{80}$ and he admitted that bounties on manufactures

75 Supra note Ig.

${ }^{76}$ Mill, Dissertations and Discussions ( 1865$), 338$; Mill says that Bentham owes his permanent importance to the fact that he was something more than a critic of abuses; "he made it a point of conscience not to (assail error) until he thought he could plant instead the corresponding truth. . . . . He began de novo, laid his own foundations deeply and firmly, built up his own structure and bade mankind compare the two."?

77 Proceedings of the British Academy, $x, 450$.

78 "Their extreme reliance on such deductions goes to the root of the criticism by Adam Smith of their doctrine. It made their system one for the middle of the eighteenth century; while that of Adam Smith had a broader basis through which it became the inspiration of statesmen in the nineteenth century." Ibid. $450-45$ r.

${ }^{79} 3$ Cunningham, Growth of English Industry and Commerce (5th ed. 1917), 738.

${ }^{80}$ I Smith, Wealth of Nations (Cannan's ed. I904), 428-429. 
necessary for the defence of the nation were justifiable. ${ }^{8 x}$ He admitted also that there were cases in which it might be wise to impose import duties. For instance, if a tax was imposed on a native commodity, it was reasonable to impose a similar tax on the same commodities imported from abroad $;^{82}$ and high duties or prohibitions imposed by foreign states on native commodities might be subjected to retaliatory taxes, "where there is a probability that they will procure the repeal of the high duties or prohibitions complained of." ${ }^{33} \mathrm{He}$ admitted that it was not desirable to repeal suddenly high duties on, or prohibitions of, foreign products when those duties or prohibitions had resulted in the establishment of native industries ${ }^{84}$ - "were these high duties and prohibitions taken away all at once, cheaper foreign goods of the same kind might be poured so fast into the home market, as to deprive all at once many thousands of our people of their ordinary employment and means of subsistence. The disorder which this would occasion might no doubt be very considerable." ${ }^{\prime 85}$ He did not condemn the laws which fixed the highest rate of interest which could be charged for loans of money; ${ }^{86}$ and, though his views were perhaps shaken by Bentham's arguments in his Defence of Usury, he did not alter his book. ${ }^{87}$ Probably he saw what Bentham and later economists did not see, that some legislation on this topic is necessary to prevent "the extortion of usury." issue of notes for small denominations, although it might "be considered as in some respects a violation of natural liberty," on the ground that "those exertions of the natural liberty of a few individuals, which might

${ }^{8} 2$ ibid. 23.

82 I ibid. 429.

${ }^{83}$ I Smith, Wealth of Nations (Cannan's ed. I904), 432.

84 工 ibid. 433 .

${ }_{5} \mathrm{He}$ adds, however, that the disorder would probably be less than is commonly imagined, first because manufactures now commonly exported without a bounty would not be affected, and secondly, because those thrown out of employment would probably be absorbed in other industries-more especially if the privileges of corporations and the law of settlement were abolished, I $i$ bid. $433-435$; this was one of the arguments against the proposed commercial treaty with France in I7I3, -it would, it was said, destroy our incipient sill and paper manufactures and throw thousands out of employment, 6 Parliamentary History of England (Cobbett's ed. $x 8$ ro), I2rr.

${ }^{86}$ I Smith, Wealth of Nations (Cannan's ed. r904), 338-339.

${ }^{87}$ Rae, Life of Adam Smith (r895), 422-424. Mr. Rae thinks that "if Smith had lived to publish another edition of his work, he would have modified his position on the rate of interest"; it appears from a letter written by George Wilson to Bentham, which purported to relate what he had heard from Adam Smith, that Adam Smith had said that "the Defence of Usury was the work of a very superior man, and that tho' he had given him some hard knocks, it was done in so handsome a way that he could not complain, and seemed to admit that you were right"; this does not amount to a complete surrender to Bentham's views.

${ }^{88}$ See 8 Holdsworth, History of English Law (I926), roo-Ior. 
endanger the security of the whole society, are and ought to be restrained by the laws of all governments; of the most free, as well as of the most despotical." $" 89$

It is perhaps regrettable that Smith did not consider more fully all the implications of these modifications of his leading principles, and especially the implications of the principle laid down in the passage which has just been cited. He had a very low opinion of the patriotism and the commercial morality of manufacturers and traders. ${ }^{\circ 0}$ Manufacturers, he considered, were always in a tacit combination to depress their workmen;"r and he pointed out that whilst they combined with impunity, workmen who combined were criminally prosecuted..$^{92} \mathrm{He}$ considered also that these manufacturers and traders were generally interested in deceiving and oppressing the public, and that they had "upon many occasions both deceived and oppressed it."93 But, if this was so, it followed, first, that the abolition of all the laws which protected the workmen could hardly be justified, for it obviously played into the hands of these crafty and unscrupulous manufacturers; and, secondly, that the popular fear of the engrosser and forestaller was not a mere superstition comparable to the popular fear of witchcraft.94 His view that these crafty manufacturers had succeeded in deceiving the honest and ignorant country gentlemen, and so had induced the legislature to fetter trade in their own selfish interests, ${ }^{95}$ can hardly be supported. The country gentlemen were not so simple as he imagined. There were sometimes other reasons, which outweighed the purely economic reasons, for the laws which they passed. It was necessary to give some initial measure of protection to infant manufactures-as many nations before and since Adam Smith wrote have discovered; and he himself admits that, though the wealth of a neighbouring nation "is advantageous in trade," it may be "dangerous in war and

${ }^{89}$ I Smith, Wealth of Nations (Cannan's ed. I904), 307.

90 "The capricious ambition of kings and ministers has not, during the present and preceding centuries, been more fatal to the repose of Europe than the impertinent jealousy of merchants and manufacturers. The violence and injustice of the rulers of mankind is an ancient evil, for which, I am afraid, the nature of human affairs will scarcely admit of a remedy. But the mean rapacity, the monopolizing spirit of merchants and manufacturers, who neither are, nor ought to be, the rulers of mankind, though it cannot perhaps be corrected, may very easily be prevented from disturbing the tranquillity of anybody but themselves." $x$ Smith, Wealth of Nations (Cannan's ed. r904), 457, 458.

9x I ibid. 68.

92 工 ibid. 68-69, I43-I44.

942 ibid. 35.

${ }^{93}$ I ibid. 250.

95 I ibid. 249-250, 400-40I, 426-427. 
politics." ${ }^{96}$ Similarly the prohibition of the cultivation of tobacco in England, which he condemns, ${ }^{97}$ was an integral part of the price paid to the colonies for the system of the Acts of Trade. ${ }^{98}$ His contention that the trade in intoxicating liquors should be free because their cheapness was always a cause "not of drunkenness but of sobriety,"99 was contradicted by recent experience, which had led to the passing of Acts which controlled the sale of gin. ${ }^{\text {.oo }}$

That a reconsideration of industrial and commercial policy was needed, in view of the great changes which were taking place in industrial and commercial conditions, was obvious; and there is no doubt that one of the changes needed was a repeal of statutes which imposed out of date restrictions upon the conduct of native industries, and that another change was a revision of statutes which regulated foreign trade, so as to secure greater freedom of trade. These changes fitted in very well with Adam Smith's theories as to the beneficent effects which might be expected to result from leaving traders free to conduct their businesses as they pleased; for those theories obviously led to the conclusion that the less the state interfered the better. According to Adam Smith the state "has only three duties to attend to . . . . first, the duty of protecting the society from the violence and invasion of other independent societies; secondly .... the duty of establishing an exact administration of justice; and, thirdly, the duty of enacting and maintaining certain public works and certain public institutions which it can never be for the interest of any individual, or small number of individuals, to erect and maintain." strict the sphere of state action, at a time of industrial and commercial transition, was very dangerous. To give manufacturers and traders the power to conduct their businesses exactly as they pleased at such a time, was really inconsistent with the opinions which he himself held as to the commercial morality of those persons-and yet that was the conclusion to which his theories led, and which, with a few modifications, he advocated. When, from Adam Smith's theories, his successors constructed a science of political economy which was even more rigid and more scientific than that set forth in the Wealth of Nations, and when Parliament sur-

96 "The wealth of a neighbouring nation, though dangerous in war and politics, is certainly advantageous in trade." I Smith, Wealth of Nations (Cannan's ed. I904), 458.

97 I ibid. 158.

$9^{8} 6$ Holdsworth, History of English Law (I924), 322.

99 I Smith, Wealth of Nations (Cannan's ed. I904), 456-457.

${ }^{100} 2$ Lecky, History of England ( 1878 ), too-ro5.

${ }^{\text {rox }} 2$ Smith, Wealth of Nations (Cannan's ed. x904), I84-I85. 
rendered its judgment upon industrial and commercial problems to the professors of this new science, it augured ill for the future development of British industry and commerce. The first fruits of this surrender were the abandonment by Parliament of the attempt to adjust equitably the relations of capital and labour. Its later fruits were the inauguration of a system of one-sided free trade, which led to loss of that lead in industry and commerce, which Great Britain had secured in the days when the despised mercantilists had worked successfully to secure its predominance.

The a priori theories of economics and legislation-theories which in England are associated with the names of Adam Smith and Benthamhad a vast influence upon the legislation of the nineteenth century. They did good service in clearing away much obsolete law which was quite out of harmony with modern conditions. They did good service in bringing to the front new points of view, and new proposals for legislation, which were more in harmony with these conditions. But it is always dangerous for a legislature, which must deal with the practical problems which changing conditions set to the state, to surrender completely to an $a$ priori theory; and the more logical and more scientific the theory the more dangerous it is to surrender to it, for it is not by logic alone that these problems can be solved. Unregenerate human nature will generally find a way to turn to its own selfish uses the rigid rules which logic dictates. If the legislature had surrendered as completely to all the proposals of Bentham and all the theories of Austin as it surrendered to the economic proposals and theories of Adam Smith and his successors, the effects upon the English political and legal system would have been as disastrous as the effects of this surrender were upon the industrial and commercial policy of the English state. ${ }^{\mathrm{T} 2}$

W. S. HoLDSWORTH

Alt Souls College, OXFORD

soz "The school of analytical jurisprudence, founded by Austin made English lawyers and statesmen realize the theory of sovereignty more distinctly than they had ever realized it before. But . . . . they refused to become its slaves. . . . . Austin's Jurisprudence was published in 1832 ; and during the succeeding years of the nineteenth century its influence was great. But the leading principles of responsible government were developed in Canada between $184^{\circ}$ and $r 850$, and were applied to the other great Dominions long before the end of the nineteenth century." Holdsworth, Lessons from our Legal History, (I928) I3I-2; similarly, the reforms in the land law made by the legislation of the nineteenth century, though influenced by Bentham, followed a course very different from that which Bentham would have deduced a priori from the principle of utility, see Holdsworth, Historical Introduction to the Land Law, (r927) chap. IV. 